\title{
Portugal's Quota-Parity Law: An Analysis of its Adoption
}

\author{
MICHAEL BAUM and ANA ESPÍRITO-SANTO
}

\begin{abstract}
In August 2006, Portugal approved a new quota law, called the parity law. According to this, all candidate lists presented for local, parliamentary, and European elections must guarantee a minimum representation of 33 per cent for each sex. This article analyses the proximate causes that led to the adoption of gender quotas by the Portuguese Parliament. The simple answer is that the law's passage was a direct consequence of a draft piece of legislation presented by the Socialist Party (PS), which enjoyed a majority. However, the reasons that led the PS to push through a quota law remain unclear. Using open-ended interviews with key women deputies from all the main Portuguese political parties, and national public opinion data, among other sources, the role of four actors/factors that were involved in the law's adoption are critically examined: notably, civil society actors, state actors, international and transnational actors, and the Portuguese political context.
\end{abstract}

\section{Introduction}

In recent years there has been a tremendous growth in the number of countries that have adopted gender quota policies ${ }^{1}$ as a means of redressing the persistent gender imbalance in political representation. More than half the world's political systems (at least 110 as of 2009) now utilise some form of 'positive discrimination' or 'fast track' quota strategy to help more women get elected (Dahlerup 2006: 218-26; Dahlerup and Freidenvall 2005; Global Database of Quotas for Women 2009; Krook 2006b; The Economist 2008), and most of these reforms have appeared within the last 15 years (Krook 2009; Krook et al. 2009a). ${ }^{2}$ Not surprisingly, despite the controversial nature of quota policies, their relatively quick diffusion across various regions and types of political systems has led to a large and expanding research agenda focused on a wide array of important theoretical and policy questions (Dahlerup 2008; Krook 2009). Condensed to its essence, the literature on quotas has focused primarily on (1) explaining why

Correspondence Address: mbaum@umassd.edu; ana.espirito.santo@eui.eu 
quotas are adopted and/or (2) why they have had differential effects on a wide range of potential dependent variables (see Krook et al. 2009a: 2-3).

This article attempts to build comparative knowledge primarily in the first area, as it seeks to answer the question as to why quotas were adopted as an institutional reform in Portugal. This type of reform is all the more puzzling since gender quota laws are almost always adopted, as in the Portuguese case, by overwhelmingly male legislatures. So why do they do it? By following more or less explicitly the conceptual model provided by Mona Lena Krook (2009) as well as the seminal works of Drude Dalherup (2006) and Joni Lovenduski and Pippa Norris (1993; Norris and Lovenduski 1995), we seek to overcome some of the inherent problems of single-country case studies. ${ }^{3}$ We chose this path for two reasons: first, to date nothing has been published about the adoption of the Portuguese quota law in English; ${ }^{4}$ second, it is too early to analyse the success of its implementation or other consequences that it might produce on citizens' political attitudes in the future. In Portugal, apart from existing research on the condition of women in general (Cabral 1997; Ferreira 1999), there are other studies which focus on women's status in politics (Baum and Espírito-Santo 2004; Bettencourt and Pereira 1995; Campos 2005; da Silva 1993; Espada et al. 2002; Viegas and Faria 2001). There is, however, a significant lack of scholarship on the implications of political institutions for women's participation in politics. ${ }^{5}$

This study is based on two different sets of original primary data. The first comes from a project coordinated by André Freire and José Manuel Viegas (2009) that includes a national public opinion poll of eligible voters completed in 2008. ${ }^{6}$ The second comes from a project developed by Ana Espírito-Santo in 2005. That study provides content analysis of electoral programmes presented by each party before each legislative election from 1976 to 2005 and semi-structured face-to-face interviews conducted with 19 people, ${ }^{7}$ most of whom were women who either currently or formerly served as MPs from all the analysed parties (Espírito-Santo 2006). With respect to the role of opinion makers in the print media, we rely on content analysis of newspaper editorials and coverage carried out by two Portuguese communication scholars (Silveirinha and Peixinho 2008).

The article is organised as follows. After a review of the literature on the adoption of gender quotas, we contextualise the Portuguese parity law. Thereafter, we dedicate one section to each of the actors/factors that played an important role in the adoption of the parity law. The main factors we identified are organised into four groups of variables: civil society (f)actors such as the Portuguese print media and key opinion makers; state actors, such as the political parties (including their women's organisations) and the President of the Republic; international and transnational actors, including EU and international organisations and transnational parties; and finally local political context variables, in this case, Portuguese public opinion and the role of the electoral system. We then develop our conclusions in light of research findings on the adoption of quota laws in other countries. 


\section{Models of Gender Quota Adoption}

To date, most of the research on the adoption of gender quotas has taken a case-study approach, focusing on their adoption in single countries or possibly their diffusion within a certain world region (Dahlerup 2006; Matland and Montgomery 2003). In what is almost certainly the most upto-date effort to integrate this burgeoning case-study literature into a coherent conceptual framework, Mona Lena Krook (2009) takes a global perspective and organises her seminal literature review in such a way as to provide a useful template for our own analysis of the Portuguese case.

Krook (2009: 9-11) argues that studies of gender quota adoption have essentially provided four main accounts. First, numerous studies have found that women's groups are usually at the forefront of any push for quota measures. Such groups may include women's sections within political parties, women's movements outside of the parties within civil society, international women's groups, and even individual women close to powerful men (Kittilson 2006; Krook 2006a). Because women's increased access to the political resources thought to be crucial for breaking the glass ceiling in politics have only provided for glacial progress to date, these groups view quotas as necessary as a 'fast-track' strategy to significantly enhance women's representation in politics (Bacchi 2006; Dahlerup and Freidenvall 2005).

A second account tends to focus on the role of (typically male) political elites and their strategic reasons for adopting quota measures. As Krook (2009: 9-10) reminds us, various case studies highlight the importance of contagion - as party elites often adopt quotas when one of their rivals adopts them (Caul 2001; Meier 2004). Similarly, case studies from Brazil (Htun and Jones 2002) and France (Bird 2003) show that elites may also sometimes use quotas as an empty gesture, 'as a way to demonstrate a degree of commitment to women without actually intending to alter existing patterns of inequality' (Krook 2009: 10). Alternatively, elites may sometimes use quotas 'as a convenient means to achieve other ends, like maintaining control over rivals within or outside the party' (Krook 2009: 10; Panday 2008). These stories of quota adoption remind us that political elites often have conflicting motives for enacting such a reform.

A third set of studies suggests that quotas are adopted when they mesh with 'existing or emerging notions of equality and representation' (Krook 2009: 10). One of the more consistent findings in the literature has been the correlation between quota adoption and left-wing parties, which are generally more open to measures designed to promote greater social equality (see Bonomi et al. 2006; Norris and Lovenduski 1995; Opello 2006; Paxton and Kunovich 2003), although Dahlerup (2006) cautions us about the numerous exceptions to this rule. Others see gender quotas as just another tool that seems to fit well with more consociational types of democracies, to use Lijphart's term (1999). These democracies tend to be 
associated with electoral systems that favour a more proportional form of representation for different groups in society, for example those based on different linguistic, religious, racial, or other categories (Matland and Montgomery 2003; Matland and Taylor 1997). While such studies are relatively loose in their association with one another, they can be said to share arguments that analyse quotas in terms of their degree of 'fit' with the specific features of the national political context - either institutionally or attitudinally.

A fourth account suggests that international norms and networks help to spread the gospel of gender quotas through transnational sharing. Krook (2009: 10-11) suggests that these norms can shape national quota debates in at least four ways. The one that most clearly applies to the Portuguese case is through transnational emulation, which occurs where transnational NGOs share information about quota strategies with local women's movements (and/or women's groups within national political parties).

Thus, based in part on the approach identified by $\operatorname{Krook}(2007,2009)$, Table 1 presents the actors that we identify as having been significantly involved in the quota adoption process in Portugal. Since these agents and factors interrelate with each other, their formal separation here is meant merely as a heuristic device. For instance, the mass media and its key opinion makers might be expected to have a substantial impact on public opinion, and party elites clearly pay heed to public opinion and civil society actors as they develop their strategies and positions, all three of which may be influenced by international actors. We also recognise that opposition parties, while not state actors per se, seek to capture state power and are privileged social actors in the Portuguese context in ways that other civil society actors are not. Finally, we are aware that drawing a clear boundary between political parties and civil society groups is fraught with difficulties (USAID 2004; Ware 1997).

Amongst civil society actors, the role of NGOs is obviously missing. Although we did analyse the role of national women's rights NGOs on this debate, ${ }^{8}$ we concluded that it was not a crucial one - besides the fact that it was heavily influenced by transnational networks and actors - and therefore decided to leave it out due to space limitations. ${ }^{9}$

TABLE 1

ACTORS/FACTORS DIRECTLY OR INDIRECTLY INVOLVED IN THE QUOTA ADOPTION IN PORTUGAL

\begin{tabular}{lccc}
\hline $\begin{array}{l}\text { Civil society } \\
\text { actors }\end{array}$ & State actors & $\begin{array}{c}\text { International and } \\
\text { transnational actors }\end{array}$ & $\begin{array}{c}\text { Political } \\
\text { context }\end{array}$ \\
\hline $\begin{array}{c}\text { Mass media and } \\
\text { opinion makers }\end{array}$ & $\begin{array}{c}\text { Political parties Women's } \\
\text { organisations (within } \\
\text { parties) }\end{array}$ & $\begin{array}{c}\text { Transnational parties } \\
\text { European and } \\
\text { President of the Republic }\end{array}$ & $\begin{array}{c}\text { Public opinion } \\
\text { organisations }\end{array}$ \\
\hline
\end{tabular}


With these caveats in mind, this article seeks to understand which actors played the most important role in the adoption of the parity law as well as the motivations behind the actions of each player. Before proceeding with that examination, let us briefly contextualise the Portuguese 'parity' law.

\section{Contextualising the Portuguese Law}

The military coup of 25 April 1974 marked the end of 48 years (1926-1974) of authoritarian rule in Portugal and led to the establishment of a democratic regime. Only after this date did women and men start gaining the same rights under Portuguese law. The principle of equality was guaranteed by the Portuguese Constitution, which became effective on 25 April 1976.

The fourth revision of the Constitution (de Sousa et al. 1997) was particularly important for two reasons. Firstly, among the state's responsibilities, it introduced in Article 9 the duty 'to promote equality between men and women'. Secondly, two major changes were made to Article 109, which refers to the citizens' rights to political participation. The reference to 'direct and active participation of citizens in political life' was changed to refer expressly to 'men and women', and it gave to the law the task of and even the duty, advance special measures of positive discrimination to ensure women's political participation: 'the law must promote equality in the exercise of civic and political rights and non-discrimination in terms of gender regarding access to public positions' (de Sousa et al. 1997: Article 109).

The first attempt to introduce a gender quota law followed shortly thereafter, in $1998 .^{10}$ It was introduced by the centre-left Socialist Party (PS), which at that time controlled only 112 of the 230 seats in Portugal's unicameral Parliament or Assembly of the Republic (VII Legislature, 19951999). After the 1999 elections, the PS retained exactly half of the seats in the Parliament (VIII Legislature, 1999-2002). Parliament rejected the 1998 proposal and two other bills introduced in 2000 and $2003^{11}$ by the PS as well as two more introduced in 2001 and $2003^{12}$ by the more extreme-left Left Bloc (BE). All these bills introduced a fixed number of candidates of each sex on party nomination lists. In April 2006, however, the PS now enjoyed a majority in the Parliament and its bill, ${ }^{13}$ along with three bills from the $\mathrm{BE},{ }^{14}$ passed on their general principles ${ }^{15}$ in the Assembly of the Republic with the support of all PS and BE MPs. These four bills were very similar. Both proposed the adoption of 33 per cent minimum representation of each gender at all three levels (local, legislative, and European), and both used the word 'parity' in the title as well as in their content. The word 'parity' was absent only from the first bill that each party presented (1998 for PS and 2000 for BE), even if none of the bills proposed truly equal access to elective positions, which is the usual definition of 'parity' (Opello 2006: 8). ${ }^{16}$

There were two differences between the 2006 bills: while the former suggested the approval of a totally new law, the latter opted for changing the 
existing electoral law. The second difference is that the introduction to the BE's bills mentioned the importance of having a proportional electoral system for the election of women - an idea to which the PS tends to be less committed, given ongoing debates about the future of the country's electoral system (Freire et al. 2008).

Eventually the consolidation of the four approved bills led to the publication of a decree by the Assembly of the Republic. ${ }^{17}$ Vetoed by the President in June 2006, who considered the sanctions envisioned by the decree as excessive, the decree was sent back to the Assembly and amended. ${ }^{18}$ The main amendments were: first, the imposition of fines on parties with non-compliant lists instead of the initial outright rejection of such lists and, second, the insertion of an article requiring that the parity law be re-assessed in five years' time based on its impact on gender balance in Portuguese electoral politics. The bill passed again, although this time only with the support of the PS. The main reason for the BE's decision not to sign it was the less stringent sanctions. The new decree ${ }^{19}$ was promulgated by the President of the Republic in August 2006 and the parity law published on 21 August $2006 .{ }^{20}$

According to the parity law, the lists for the Assembly of the Republic, the European Parliament, and local elections shall be composed in such a way as to ensure a minimum representation of 33 per cent from both genders. In order to guarantee this, the multi-member lists presented cannot contain in consecutive order more than two candidates of the same gender (what is frequently referred to as the 'zipper principle'). The latter rule, however, does not apply to the composition of lists for the bodies of communities (freguesias) with 750 or fewer voters or for municipalities (municipios) with 7,500 or fewer voters. ${ }^{21}$ These correspond at the moment to 1,800 communities (42.3 per cent of the total number of communities) and 76 municipalities (24.7 per cent of the total number of municipalities). ${ }^{22}$ Noncompliance with the quota will result in a $25-50$ per cent reduction in public subsidies for the electoral campaign of said party/coalition. A 50 per cent reduction is applied when the presence of one of the genders is lower than 20 per cent, while when that presence is equal or superior to 20 per cent but lower than 33 per cent, the reduction is of 25 per cent. Non-compliance with the candidate order rule also results in a 50 per cent reduction. None of these punishment mechanisms applies if the list is shorter than three candidates. ${ }^{23}$

\section{Civil Society Actors}

\section{Mass Media and Opinion Makers}

Since the debate over gender quotas in Portugal played out in the public sphere, it is important to consider the role of mass media (particularly television, the main channel through which most Portuguese receive their political news) and of key opinion makers. By opinion makers we mean the 
class of paid editorial writers and political commentators who regularly appear in print and on television news shows, otherwise known in many countries as 'public intellectuals'. While they have been a regular feature of the Portuguese media for some time, to date the role of these privileged actors in the gender quotas debate has not been well documented. Our analysis draws on work by two scholars of Portuguese media and communication (Silveirinha and Peixinho 2008). Their data consists of all opinion articles published in the main Portuguese newspapers in 1999 (regarding the 1998 PS bill) and of 2006 (on the parity law). Silveirinha and Peixinho's dataset comprised 30 and 29 articles respectively for each year.

As regards the two key moments of public discourse on the matter of gender quotas in Portugal, in 199915 texts expressed a position against the quotas law, eight in favour, and seven were broader analyses without a clear position. In 2006 there was more balance in argued positions: 15 texts were pro-quotas, 12 opposed them, and two did not take a stand (Silveirinha and Peixinho 2008: 5). So clearly opinion makers and print media editors provided a more receptive environment for gender quotas in 2006 than the first time this issue entered into Portuguese public discourse.

According to this study, in both periods the issue was primarily defined in terms of the numerical deficit of women in Portuguese politics, though in 2006 more texts mentioned other forms of gendered discrimination in Portuguese society. Curiously, several of the 2006 texts noted how many other countries around the world had adopted some form of legal gender quotas, whereas in 1999 opponents cited the relative dearth of these examples in Europe as a reason for opposing them. In other words, attention to what was happening outside Portugal appears to have had a significant influence on the debate in 2006, as many authors cited the need to avoid laggard status in these matters. Additionally, while in 1999 the term 'quotas' was the key word used, in 2006 'parity' became the name of the law, despite the fact that none of the bills actually proposed a 50 per cent distribution of candidates by gender (Silveirinha and Peixinho 2008: 8). Previous research on Portuguese voters' behaviour in referenda, for example on abortion and regionalisation, also suggests that language and framing matter greatly (Baum and Freire 2003; Freire 2008), and so this linguistic turn of phrase appears to have been useful for supporters of gender quotas.

\section{State Actors}

\section{Political Parties}

Although both the PS and the BE were clearly involved in the adoption of the parity law, their roles were distinct. The most obvious difference between the parties is that the BE did not support the amended version of the decree, drafted after the President's veto that eventually became law. The imposition of fines on political parties with non-compliant lists instead of 
the rejection of such lists was not acceptable to the BE, which preferred a stronger sanction for parties not complying. Nevertheless, both parties are associated with the defence of higher women's representation in politics in Portugal.

The PS was formally founded in exile in Germany in 1973 during the Portuguese dictatorship. ${ }^{24}$ Since 1976 its strategy towards gender equality has evolved dramatically. In the first decade of democracy, the average percentage of women occupying eligible places on the PS candidate lists and those actually elected did not reach 5 per cent. However, during the seventh Party Congress (1988) an important measure for gender equality was implemented at the suggestion of Vítor Constâncio (PS leader between June 1986 and February 1988). The measure was an internal quota system of 25 per cent, which was approved for both the national party organs and all multi-member lists.

Although this measure had some immediate consequences for the numbers of women elected both to the national Parliament and national party organs, it was not fully implemented until 1999, due to internal opposition within the PS (mentioned by Vitor Constâncio in a personal interview). From 1995, however, the PS intensified its strategy of supporting the election of women and officially defined itself as a party committed to increasing women's presence in politics. The most important step in this direction was its support, outlined for the first time in the electoral programme of 1995, for positive discrimination measures (PS 1995: 1-5). This then forced the party to fully implement its internal quota system at the next scheduled elections in $1999,{ }^{25}$ leading to a considerable increase in the percentage of Socialist women representatives in the national Parliament. Between 1995 and 2005, an average of 21.2 per cent of PS MPs were women, ${ }^{26}$ while the average proportion of PS women candidates reached nearly 25 per cent. On several occasions since 1998 the PS has presented draft legislation proposing the nationwide implementation of positive discrimination measures to support the election of women. The last of these became the parity law.

Whereas the PS took over 10 years to fully adopt the concept of gender quotas, the BE has placed increasing importance on women's representation within political structures ever since its founding in 1999. Over the last few years, the BE's intensified interest has been evident in the content of its electoral programmes as well as in the proportion of women the party has elected to the national parliament. It has always had a sizeable percentage of women on its candidate lists (on average 39 per cent). In the 2005 legislative elections, the BE elected eight MPs, four of whom were women, and as of the September 2009 elections, six of the BE's 16 MPs are now women. According to both of the BE MPs interviewed, this happened because the BE follows a 'soft quotas' measure of 33 per cent, as described by Krook et al. (2009b: 784). ${ }^{27}$ As already mentioned, after 2001 the BE presented two bills - both of which were defeated - that promoted greater gender balance 
in all multi-member lists. In 2006 the party presented other bills which eventually became incorporated into the parity law.

In Portugal, the more left-wing a party is, the higher the percentage of women it elects (see Figure 1). According to a questionnaire answered by Portuguese experts in $2003\left(\mathrm{CSES}^{28}\right)$, on a left-right continuum (where $0=$ left and $10=$ right), the $\mathrm{BE}$ is the most leftist Portuguese party (1), followed by the Portuguese Communist Party (PCP) (2). The PS occupies a more central position, still slightly to the left (4). The two remaining parties are the more right-wing Social Democratic Party (PSD) (7) and the Centre Democratic Christian-Popular Party (CDS-PP) (8).

First observable in the early 1990s, the tendency for left-wing parties to elect more women has become more pronounced since the 1999 elections (see Figure 1). The overall rate of feminisation of the Portuguese Parliament has also steadily increased in that period, rising from 7.6 per cent in 1987 to 27.4 per cent in 2009 (CNE 2009).

However, the influence of ideology was already evident at the beginning of the democratic period, in the late 1970s. When the topic of women's political representation was far from reaching the visibility that it has at the moment, the Communist Party already had the highest proportion of women elected representatives among the parties. ${ }^{29}$ The PCP was also the first Portuguese political party to defend the importance of greater women's participation in politics in its party manifesto (PCP 1979: 7). However, the Communists voted against all bills that aimed at implementing quotas on the grounds that the gender gap in political participation had socioeconomic origins and that such quotas would be only a pyrrhic solution.

The remaining parties are the PSD and the CDS-PP. The strategy of the PSD towards women has rather undefined contours, not only because the party suffered oscillations in strategy resulting from leadership changes, ${ }^{30}$ but also because the PSD encompasses a variety of opinions on this

FIGURE 1

PERCENTAGE OF WOMEN MPS BY PARTY (1976-2009)

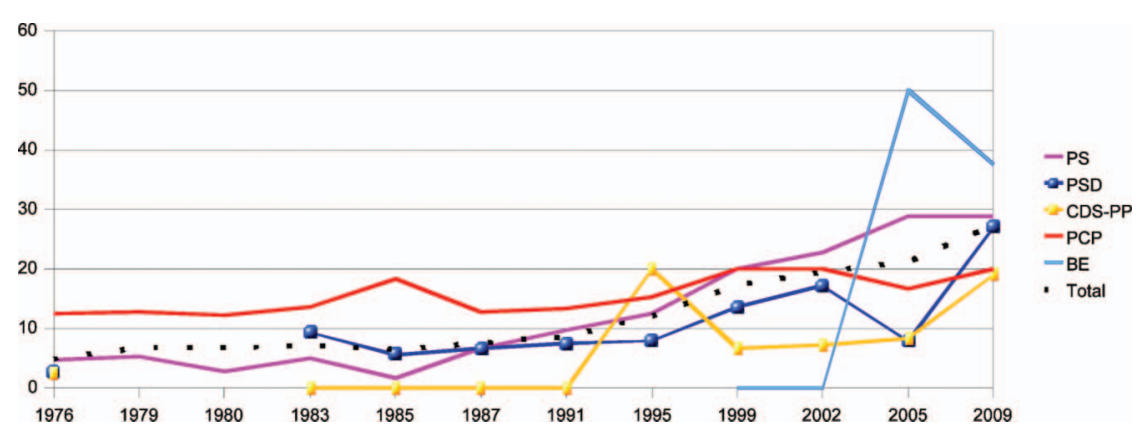

Notes: Socialist Party (PS), Social Democratic Party (PSD), Centre Democratic Christian Party (CDS-PP), Portuguese Communist Party (PCP) and Left Bloc (BE). 
matter. ${ }^{31}$ Despite this, the official PSD position was (and still is) completely opposed to quotas. In fact, the PSD voted against all bills related to quota system implementation on a national level. ${ }^{32}$

The same applies to the more homogeneous CDS-PP, whose official stance against quotas was upheld by the women MPs interviewed. For the latter, gender equality in politics was not an important issue for the party because there was no gender discrimination within the party. However, as Figure 1 indicates, its percentage of women representatives has always been very low (the exception being the 1995 elections).

Several authors agree that notwithstanding its rejection, the first PS bill (1998) on positive discrimination mechanisms for women contributed tremendously to increasing public exposure of this issue in Portugal (Jimenez 2002: 293; Meirinho Martins and Teixeira 2005: 83; Viegas and Faria 2001: 51). In fact, Figure 1 demonstrates that, since the mid-1990s, all political parties have seen increased women's representation in their parliamentary groups. Both Jimenez (2009: 240-41) and Viegas and Faria (2001) argue that this is evidence of how parties in government can set the agenda and exercise influence over the gender policies of parties in the opposition.

The BE's actions have also probably had an influence on other parties, in particular the PS, in terms of raising awareness of the issue of women's political representation. For both the PS and the BE MPs interviewed, their party was the main advocate of this issue in Portugal.

\section{Women's Organisations (within Parties)}

In Lovenduski and Norris' view (1993: 14), 'there is no party in which efforts to nominate more women have occurred without an intervention by women making claims'. Furthermore, Jiménez (2002: 470), in her comparative study of the PP (Spanish) and PSD (Portuguese) cases, concluded that one of the predictors that makes the PP less conservative in regard to 'women's issues' is the fact that the PP, unlike the PSD, had a strong women's organisation (Jiménez 2002: 470).

Among the Portuguese political parties, the three more left-wing parties, namely the BE, PCP, and PS, all have internal women's organisations either in the form of an established department (PCP and PS) or a working group (BE). The influence of these organisations is very hard to prove, given its low-profile, indirect character, and the fact that most initiatives are carried out by men, since men assume the overwhelming majority of important political positions. A good example of this difficulty is the quota system adopted by the PS in 1988. As previously mentioned, Vitor Constâncio, who was then the President of the PS, proposed the adoption of this measure. However, it is unclear whether the idea was originally his or whether he was influenced by an individual woman or group of women within the party. This seems likely considering that, during the 1986 Congress, PS member 
Maria Belo put forward a motion officially raising this particular issue for the very first time. The Socialist, Communist, and BE MPs interviewed stated that most of the evolutionary processes their parties have experienced around women's issues can be attributed to the actions of (some) women, irrespective of these individuals' membership in women's departments or organisations.

Finally, there are no formal links between the few NGOs focused on gender discrimination issues and leftist political parties, though it is fair to assume a certain amount of ideological sympathy, especially with respect to the former's efforts to enhance the visibility of gender discrimination issues within Portuguese society. Furthermore, the connection between NGOs and parties is even more likely since they are all represented in the Advisory Council of the main Portuguese gender equality institution (Commission for Citizenship and Gender Equality), where the agenda of 'parity democracy' was highly consensual (Monteiro 2011).

\section{The President of the Republic}

The President of the Republic (Aníbal Cavaco Silva) played a key role in the adoption of the parity law since his veto of the first version of the decree led to a new version with softer sanctions on parties in non-compliance. In other words, without his intervention the law would be a stronger one. It would not include the revision of the law in five years and, instead of fines, it would provide for the outright rejection of non-compliant party lists. The President considered the latter measure excessive, disproportionate and therefore inadequate to fulfil the objective of the law. In his opinion, draconian punishment mechanisms would threaten both the freedom of the parties and the dignity of the women elected (DAR II série A No.120/X/1 2006.06.14, $2-3)$. He also cited the difficulties the original law would engender for parties organising lists in local elections, particularly in interior municipalities where the electorate is numerically small and more elderly than in large urban districts (Público 2006).

Given the President's affiliation to the PSD, a party officially opposed to quotas, his decision not to use the constitutional powers at his disposal to veto the law entirely or to send it for judicial review is to be noted. A precedent had been set in France in 1982, when judicial review by the Constitutional Court managed to block Parliament's passage of a 25 per cent quota law (Opello 2006: 8). By contrast, President Cavaco Silva chose not to ask the Constitutional Court to study the constitutionality of the law, despite calls to do so by the opposition parties. In any event, the previously mentioned fourth revision of the Constitution (1997) would most likely have pre-empted the Court from declaring the law to be unconstitutional.

Despite the presidential veto that weakened the law in the eyes of its defenders, one could argue that some of the benefits of Portuguese 
semi-presidentialism were reinforced during this episode, with the President serving as a moderating influence and not a destabilising one for the government of the day (see Freire 2001).

\section{International and Transnational Actors}

\section{Transnational Parties}

This section is based on statements given by 19 people, most of whom were women who were or had been MPs when interviewed in 2005 as part of a related project (Espírito-Santo 2006). Only members of two parties, the PS and CDS-PP, referred to party families or European parties as influences on their respective party's strategy regarding the election of women. Since the CDS-PP did not contribute to the adoption of quotas, we will refer only to the PS.

With respect to the question, 'Where did the PS get its inspiration for its strategy concerning women?' Sónia Fertuzinhos (previous President of the Department of Socialist Women - DNMS, 2003-05) mentioned both the Socialist International (SI) ${ }^{33}$ and the Party of European Socialists (PES). According to another PS MP, Maria do Carmo Romão, many parties belonging to the SI have women's departments, which are also represented in the SI.

In the late 1970s, the first women's organisation within the PS - the 'Socialist Women's Movement' - was created. According to a report that its founder, Mário Soares (PS leader between October 1976 and June 1996) delivered to the third PS National Congress (Soares 1979: 103), the inspiration for establishing the group came from the SI. This is the only policy measure with an origin that can be traced to the SI. However, it is safe to assume that the type of contact this organisation generates among the many usually quota-friendly social democratic parties has played at least some role in the way the party has evolved on this issue.

Irrespective of the SI, the PS might have also been influenced by other foreign social democratic parties. During the interview, Vitor Constâncio (the Socialist leader who suggested the quota system) claimed that he had been inspired by events in other European countries, particularly Norway. Furthermore, in 2000 the PS attempted to implement the parity principle on a national level through draft legislation in which a direct reference to the French case $^{34}$ was made (Government Draft Legislation No. 40/VIII, publication date: 15 July 2000: 14).

\section{European and International Organisations}

Throughout the last 50 years, international organisations have played a crucial role in advocating equality between women and men (Rees 1998; UNDP 1995). Portugal has been affected primarily by three organisations: 
the United Nations, the European Union and the Council of Europe. Although it is very difficult to identify exactly which organisation was most influential in the adoption of quotas in Portugal, it is clear that the evolution of the position of both the PS and BE regarding the election of women followed closely the evolution of those three organisations. In fact, amongst the parties under consideration, they are the only ones that have adopted strategies suggested by international precedents. This idea can be confirmed through an analysis of the parties' strategies (the adoption of the parity democracy concept is the most paradigmatic example of this ${ }^{35}$ ) and through the references to the international recommendations and guidelines contained in their draft bills, as well as their electoral programs (EspíritoSanto 2006).

In terms of the bills that eventually led to the parity law, it is striking to observe that the BE's 2006 bills clearly state that international recommendations have underlined the need to create concrete measures to guarantee the parity of genders. It goes on to give specific examples, namely the role of the Platform for Action of the 1995 Fourth World Congress on Women in Beijing, which suggested that governments improve their electoral systems in order to assure greater women's representation. It also references the Council of Europe's Recommendation No. 1269 (1995) which mentions the democratic need for greater sharing of responsibilities between the genders in all spheres of life and society, including political decision making. Although the PS's bill that led to the parity law did not include any reference to international organisations, the fact that they were present in a previous PS parity bill ${ }^{36}$ leads to the same conclusion as in the case of the BE.

\section{Political Context}

\section{Public Opinion}

As stated earlier, several studies of quota adoption have suggested that such positive forms of discrimination are enacted when they mesh with 'existing or emerging notions of equality and representation' (Krook 2009: 10). Moreover, as Inglehart and Norris (2003: 138) demonstrate, the level of a society's support for the idea of gender-balanced political leadership and the percentage of women elected to national parliament tend to be correlated.

Freire and Viegas' (2009) set of public opinion data help us to assess the degree of acceptance of parity principles amongst the Portuguese electorate, not exactly when the law passed, but in 2008. This requires some caution when analysing the data as the citizens' attitudes may have been influenced by the passage of the parity law. However, we know already from the study of Meirinho Martins and Teixeira (2005), using data from a questionnaire circulated in March 2005, that more than half of citizens (even more among 
women) were favourable to the implementation of a quota system in parliament.

To facilitate our discussion of the relevant data, we have organised the variables into the following three topics: (1) questions or statements about quotas or positive discrimination for women in general; (2) the nature of representation in general; and (3) the nature of the Portuguese Parliament and/or its parties (see Table 2).

TABLE 2

SURVEY ITEMS BY GROUP AND GENDER DIFFERENCES, 2008 NATIONAL SAMPLE SURVEY

\begin{tabular}{|c|c|c|c|c|c|c|}
\hline Topics & Questions/statements & $\begin{array}{l}\text { Men } \\
\text { agree } \\
(\%)\end{array}$ & $\begin{array}{l}\text { Women } \\
\text { agree } \\
(\%)\end{array}$ & Sig. & $\begin{array}{l}\text { Phi/ } \\
\text { Cr.V }\end{array}$ & $\begin{array}{c}\text { Missing } \\
(\%)\end{array}$ \\
\hline \multirow[t]{2}{*}{$\begin{array}{l}\text { (1) Quotas or } \\
\text { positive } \\
\text { discrimination } \\
\text { for women in } \\
\text { general }\end{array}$} & $\begin{array}{l}\text { Quotas are a necessary measure } \\
\text { to address the under- } \\
\text { representation of women } \\
\text { and increase their numbers } \\
\text { in parliament }\end{array}$ & 42.3 & 50.9 & 0.015 & 0.105 & 16 \\
\hline & $\begin{array}{l}\text { Quotas are not necessary. } \\
\text { Women should be elected on } \\
\text { merit (4-item responses, no } \\
\text { middle) }\end{array}$ & 55.6 & 53.4 & n.s. & & 10 \\
\hline \multirow[t]{4}{*}{$\begin{array}{l}\text { (2) The nature of } \\
\text { representation } \\
\text { in general }\end{array}$} & $\begin{array}{l}\text { Mechanisms that can help } \\
\text { increase the presence of } \\
\text { women in politics should be } \\
\text { created }\end{array}$ & 67 & 79.6 & 0.000 & 0.15 & 7 \\
\hline & $\begin{array}{l}\text { Men can sufficiently represent } \\
\text { the interests of women in } \\
\text { politics }\end{array}$ & 47.5 & 36.5 & 0.000 & 0.18 & 8 \\
\hline & $\begin{array}{l}\text { On the whole men make better } \\
\text { political leaders than women } \\
\text { do (4-item response, no } \\
\text { middle) }\end{array}$ & 44.5 & 21.4 & 0.000 & 0.269 & 11.3 \\
\hline & $\begin{array}{l}\text { In your opinion, an MP } \\
\text { represents above all: } \\
\text { Women, in the case of a } \\
\text { female MP and men in the } \\
\text { case of male MPs }\end{array}$ & 22.6 & 17.9 & n.s. & & 4 \\
\hline \multirow{3}{*}{$\begin{array}{l}\text { (3) The nature of } \\
\text { the Portuguese } \\
\text { Parliament } \\
\text { and/or its } \\
\text { parties }\end{array}$} & $\begin{array}{l}\text { The fact that } 80 \% \text { of MPs are } \\
\text { men is a serious threat to } \\
\text { democracy (4-item } \\
\text { responses, no middle) }\end{array}$ & 36.5 & 55.8 & 0.000 & 0.171 & 15 \\
\hline & $\begin{array}{l}\text { Parties should have an equal } \\
\text { number of men and women } \\
\text { on their candidate lists }\end{array}$ & 52.7 & 57.8 & 0.001 & 0.122 & 8 \\
\hline & $\begin{array}{l}\text { Do you feel that your } \\
\text { parliament should have } \\
\text { many more ... : Women } \\
\text { parliamentarians }\end{array}$ & 17.6 & 29.8 & 0.000 & 0.158 & 12 \\
\hline
\end{tabular}

Note: All questions included in the table have 5-item responses unless otherwise stated.

Source: Freire and Viegas (2009). 
Clearly, these questions are not ideal in terms of comparability, since they have different numbers of item responses. Be that as it may, Table 2 indicates that in terms of specific support for gender quotas and/or forms of positive discrimination more generally, Portuguese public opinion, like its counterparts elsewhere (Zaller and Feldman 1992), is extremely sensitive to question wording. For example, while about a third of respondents typically share a non-committal opinion on these items if given that opportunity, a clear plurality of electors thinks that quotas are a necessary measure to address the under-representation of women and increase their numbers in parliament' (47 per cent agree overall, 42 per cent men versus 51 per cent women; while only 20 per cent of both sexes disagree with this idea). Similarly, there is majority support for the idea that 'mechanisms that can help increase the presence of women in politics should be created' (74 per cent agree, 68 per cent men versus 80 per cent women), and that 'parties should have an equal number of men and women on their candidate lists' (55 per cent agree, 53 per cent men versus 58 per cent women; only 10 per cent disagree). In addition, of all the under-represented groups that voters could have mentioned as favouring more of in parliament, women were clearly the most favoured category ( 75 per cent saying at least some more women), compared to youth (70 per cent), the handicapped (47 per cent), blacks (38 per cent), and the elderly (23 per cent). Finally, 67 per cent of Portuguese reject the idea that 'men make better political leaders than women', which suggests a generalised rejection of essentialist arguments about gender roles in politics. On the other hand, of all the items we looked at from this survey, this item had the strongest gender gap between respondents, with 78 per cent of women rejecting this opinion against only 55 per cent of men. In light of all these items, one could argue that there is widespread diffuse support for some positive forms of discrimination in favour of women, and that support for these measures is, as we might expect, stronger among women than men. Thus, public opinion appears to be generally favourable to the parity law, confirming Meirinho Martins and Teixeira's (2005) results.

However, with different question wordings, a majority of voters are also willing to agree with the argument most often advocated by parties opposed to the quota law, namely that 'Quotas are not necessary. Women should be elected on merit' (55 per cent agree, no gender difference). Overall, voters do not see an MP's role as being primarily about representing any specific gender group, and a plurality agree that male MPs can sufficiently represent women's interests. Furthermore, when asked if they agreed with the statement that 'the fact that 80 per cent of MPs are men is a serious threat to democracy', opinion was evenly divided amongst the entire sample (48 per cent agree overall), but there was a fairly strong gender difference on this item, with only 37 per cent of men agreeing compared to 58 per cent of women $(p=0.000$; Phi 0.171$)$. In other words, as with so many public policy issues, polling will only take political elites so far in terms of helping 
them gauge how voters feel about this issue. The fact that mass attitudes about gender discrimination in Portugal vary so much depending on the item suggests that either the survey items themselves are flawed or the saliency of this issue area for Portuguese respondents is comparatively low, and therefore more prone to inconsistencies than other public policy issues of greater concern to the voter. Nonetheless, despite these inconsistencies of opinion, Portuguese respondents appear to be generally supportive of the idea of gender-balanced political leadership, which may indicate an environment where "existing or emerging notions of equality and representation' were at least not an obstacle to the new parity law.

\section{Electoral System}

Numerous studies have demonstrated a strong correlation between democracies with proportional electoral systems, in particular those with closed lists, large average district magnitudes, and centralised party-list nomination processes, as the most favourable institutional environments for electing women to parliament (Darcy et al. 1994; Htun and Jones 2002; Matland 2006; Vengroff et al. 2000). Moreover, these conditions also happen to be the most favourable institutional feature for the implementation of legal party quotas. In Matland's (2006: 281) words, '[Candidate quota laws] are almost exclusively the realm of multimember district electoral systems, usually proportional systems, but occasionally mixed systems'. Portugal fits the bill here in at least three out of the four facilitators, as it enjoys a proportional representation (PR) system with closed and centralised party lists (for most parties), though its 22 electoral districts for 230 deputies places it somewhat on the small side in terms of average district magnitude (Taagepera and Shugart 1989). Portugal's average party magnitude, namely the number of seats in each party's district delegation (see Matland 2006: 284), is also conducive to the effectiveness of Portugal's new legal quota law.

To what extent was party contagion an issue in Portugal? Matland and Studlar's (1996: 712) work on the logic behind contagion among parties suggests that as smaller but competitive parties, usually on the political fringe, start to promote women actively, larger parties will move to emulate them. This kind of contagion occurs in both majoritarian and proportionalstyle electoral systems. However, as they demonstrated by comparing the Canadian and Norwegian cases, the process will be more effective in bringing women into office and spread more quickly in multimember proportional representation systems. This is because PR systems, like Portugal's, tend to elect a greater number of parties into the system, which allows a space for smaller parties to innovate, for example in terms of nominating more women candidates. This typically pushes the mainstream parties that might have moved more slowly on the gender equity issue (in the Portuguese case this would mean the PS) to follow suit, lest they be in 
danger of losing votes to an ideologically similar party on their left (like the BE).

While this is a logical and empirical argument for the other cases examined by Matland and Studlar (1996), it only partially fits the Portuguese case. This is because the PS began its process of introducing gender quotas for its electoral lists and national party organs in 1988, long before the BE won seats in Parliament in 1999. On the other hand, it did so only half-heartedly until the mid-late 1990s. We argue therefore that the word contagion is probably too strong in the Portuguese case - partly because this issue is not sufficiently salient to Portuguese voters to warrant party to party contagion, but it seems plausible that the PS's position on gender equality was at least influenced by the rise of the $\mathrm{BE}$ as a strategic competitor on its left flank. Consequently, the PS finally started to draft legislation for legal gender quotas (1998) and implemented its own voluntary internal quotas in 1999 in part to keep up with the BE, which appeared more progressive on this and other equality issues at the time. Whether one chooses to call it contagion or influence (Caul 2001; Lovenduski 2005: 103; Meier 2004), the larger point which conforms to Matland and Studlar's (1996) findings is that if Portugal's electoral system was more majoritarian, we doubt that such innovation by a mainstream party would have happened as quickly as it did.

\section{Discussion}

This paper seeks to analyse the proximate causes that led to the adoption of gender quotas by the Portuguese Parliament. In order to do that, the role of four f(actors) were analysed, namely civil society actors, state actors, international and transnational actors, and the Portuguese political context. In general, our analysis of the Portuguese case supports several of Krook's (2009: 218-26) findings regarding the adoption of gender quota laws worldwide.

Analyses of successful parity laws elsewhere suggest that their adoption is especially open to influences from the international/transnational level, namely international emulation (Dahlerup 2008; Krook 2009; Murray et al. 2009). The Portuguese case also seems to have been particularly influenced by international organisations and transnational networks. It was definitely important for the PS's evolution regarding women's political representation - if we think of the role of the Socialist International, of other European countries that had passed quota laws since the late 1990s (such as France and Belgium), and of the recommendations of international organisations that were often mentioned in internal party documents. Since the same applies to the BE, we can say that international organisations and transnational networks helped influence party elites within the two parties, and this in turn set in motion an evolution in the country's normative debates about formal equality, democratic participation, and the need for special 
measures for women. The example of other countries was also important for the way the media started facing quotas/parity in 2006.

We would also like to underline the role of the party elites in the decision to proceed with the parity law, which represents continuity in Portuguese politics (Baum and Freire 2003). In our view, the factor that most motivated the Socialist Party to try to pass the parity law in 2006 was, firstly, transnational emulation and then the party itself, specifically key decisionmaking elites therein. Our analysis demonstrates that the PS's own ideology on this matter gradually evolved over time. From 1988, when the party first introduced the concept of voluntary 25 per cent gender quotas for its own electoral lists, to its defence of positive discrimination measures in the 1995 electoral programme, to their actual implementation in the subsequent 1999 general elections, the PS's position was slowly but clearly evolving on this issue. On the other hand, we need to be careful about assigning too much weight to the PS's growing ideological commitment to gender equality. The fact that the PS did not use the BE's two votes in the VIII Legislature (19992002) to compromise on one of the several gender quota proposals the two parties were promoting during that period suggests either a weak commitment by the PS to gender quotas at that time or a fear that they would be seen as emulators of their new rival on their left, or both (see, for example, Jimenez 2009: 253; Viegas and Faria 2001: 40). And although the PS used its majority position once back in power in 2005 to push through its quota law, the appointment of only two women ministers (out of 16) to Prime Minister José Socrates' 2005-2009 single-party majority government remains troubling. In 2005, the BE had eight seats and thus may have been perceived more and more by the PS as a real threat on its left flank. This might have influenced the PS to put the quota law into its 2005 platform and then to pass it in 2006.

Case studies from Brazil (Htun and Jones 2002), Belgium (Meier 2004) and France (Bird 2003) have shown that elites sometimes use quotas as an empty gesture, 'as a way to demonstrate a degree of commitment to women without actually intending to alter existing patterns of inequality' (Krook 2009: 10). So is this the case in Portugal as well? Overall, we do not think the 2006 parity law is just an example of lip service. Although the law did not enforce parity, and sanctions could have been tougher, its inclusion of the zipper principle meant that at least it guaranteed a more balanced representation of both genders.

What about the role of women activists themselves? Although there is not a powerful or large lobby or social mobilisation for the rights of women in Portugal, we are convinced that (some) women - and women's organisations - within the two protagonist parties were essential to call the attention of their male partners to these issues - even if their role was frequently hidden from public view. Furthermore, we agree with Monteiro (2011) that the main Portuguese gender equality institution (Commission for Citizenship and Gender Equality), where female members of each party 
(and some NGOs) are represented, might have played a role here. Regarding Portuguese public opinion, which is, as we saw, generally permissive about the desirability of having more women in politics, there is a tendency for women to be even more in favour than men. So, while we would not include Portugal within the countries where women's groups are usually at the forefront of any push for quota measures (Krook 2009: 9-11), we would not leave them out of the causes. Our argument is that relative to other countries that have passed quota laws (see other cases from this volume), the roles of state feminist and women's movement organisations in Portugal were a comparatively less important factor in the passage of the law.

Finally, our research confirms Krook's (2009: 10) emphasis on the importance of local (national) political context and how quota laws emerge based on 'new or emerging notions of equality'. From this perspective, changes in this context over time can lead to an environment that facilitates quota adoption or make it less likely. Thanks to a (failed) proposal to introduce gender quotas in 1998-1999, as well as the worldwide development of gender quotas over the past 10 to 15 years, we present evidence that suggests Portuguese media and opinion makers had been primed on this issue in 2006 in a way that was not the case earlier. In this sense, the quotas debate followed a similar process of public issue awareness that occurred between the first national referendum that sought to liberalise women's access to abortion services in 1998 (rejected) and the second referendum on abortion 10 years later, which passed (Freire 2008). Moreover, we argue that in Portugal a supportive public opinion environment (albeit one with low saliency to most voters) and a favourable electoral system served as facilitating conditions for a political party that won for the first time an absolute majority in the Parliament. Together, these factors enabled the PS to carry through on its electoral platform calling for a gender quota law.

\section{Acknowledgements}

We would like to thank all of those Portuguese MPs and political actors who agreed to be interviewed for this project, in particular the MP Helena Pinto for responding to email follow-ups. We also thank the National Committee of Elections (CNE) and the political parties for the data they provided us. Lastly we wish to thank the anonymous reviewers and Jocelyne Praud for their insightful comments, all of which made the paper significantly better. Of course, all errors of fact or interpretation are ours alone.

\section{Notes}

1. By gender quota policies we mean any of the specific means that political systems adopt to increase the number of women elected to political office. The three main types of quota measures are reserved seats, voluntary party quotas, and legislative quotas that are made 
into law, whether as part of electoral law or as a constitutional obligation. For a review, see Krook (2009: 6).

2. As of 2009, 26 European countries had adopted either voluntary or legal quota laws. Although quota laws like the parity law in Portugal have tended to be most predominant in Latin America (Matland 2006), they are quickly making inroads in the European context as well, with six countries having adopted legal quotas to date.

3. For a discussion of this problem, see Krook (2007).

4. But see, in Portuguese: Baum and Espírito-Santo (2009) and Monteiro (2011) that provides a useful critique of an earlier version of our analysis.

5. Nonetheless, see Meirinho Martins and Teixeira (2005) as well as Viegas and Faria (2001) and the as yet unpublished PhD thesis of Rosa Monteiro (2011).

6. All questionnaires were applied between 7 July 2008 and 22 September 2008.

7. All interviews took place between 21 July 2005 and 18 August 2005.

8. Three NGOs were visible in the media in favour of the adoption of the 2006 parity law: União de Mulheres Alternativa e Resposta (UMAR), the Portuguese Platform for Women's Rights (PPDM), and the Portuguese Network of Young People for Gender Equality (REDE).

9. However, our analysis of these groups and their role in the quota debate is available in English upon request, and in Portuguese in Baum and Espírito-Santo (2009).

10. Proposta de Lei 194/VII, DAR II série A No.68/VII/3 1998.07.09 (1601-1603). All bills can be found online through this website: http://www.parlamento.pt/ActividadeParlamentar/ Paginas/IniciativasLegislativas.aspx

11. Proposta de Lei 40/VIII, DAR II série A No.59/VIII/1 2000.07.15 (1884-1891), and Projecto de Lei 251/IX, DAR II série A No.76/IX/1 2003.03.13 (3221-3222).

12. Projecto de Lei 388/VIII, DAR II série A No.38/VIII/2 2001.03.03 (1453-1456) and Projecto de Lei 324/IX, DAR II série A No.110/IX/1 2003.07.04 (4430-4432).

13. Projecto de Lei 224/X, DAR II série A No.93/X/1 2006.03.11 (25-26).

14. BE presented three bills, instead of one, because they preferred to dedicate one bill to each political layer (legislative, European, local), hence three. Projectos de Lei 221/X, 222/X, and 223/X, DAR II série A No.93/X/1 2006.03.11 (17-25).

15. All bills on the same matter (presented by the different parties) are first voted on general principles on the floor of the Plenary. Those which pass are then submitted to a discussion and put to a vote on the details (i.e. article by article), usually within the parliamentary committee responsible for the specific matter. That process originates a single document termed the 'final text' which is submitted to a final overall vote on the floor of the Plenary. If it passes, it starts being termed a 'decree by the Assembly of the Republic' and is sent to the President of the Republic for enactment.

16. In most national contexts the term gender quota is usually reserved for efforts to guarantee representation (on candidate lists or in elected assemblies) at some proportion less than 50 per cent, whereas 'parity' is usually reserved for efforts that promote a democratic principle providing for the equal presence of both genders in elected assemblies, or at least women and men's equal access to elective positions. This was not the case in Portugal. When we refer to the law as the 'parity law' we are using the name it was given in the Portuguese context.

17. Decreto 52/X DAR II série A No.111/X/1 2006.05.17. See note 15 for a brief description of the Portuguese common legislative procedure.

18. We discuss the President's role in the veto and then passage of the parity law in more detail below, in the section where we analyse the roles of state actors.

19. Decreto 72/X DAR II série A No.131/X/1 2006.07.22 (10-12).

20. Lei Orgânica 3/2006, DR I série No.160/X/1 2006.08.21.

21. Each municipality (concelho) is composed of a few or many communities (freguesias). Each one of these geographical divisions has its own political body and therefore also its own electoral list.

22. This information was provided by DGAI/MAI - Administração Eleitoral, by email. 
23. From the 22 electoral districts that exist in Portugal, three elect only two MPs.

24. An earlier embryo of what would become the Portuguese Socialist Party, the ASP, was actually founded in November 1964 in Geneva.

25. In 1999, the internal quota system began being applied to the national party organs. In 2003 , the internal quota system changed from 25 to 33 per cent minimum representation of each sex.

26. Between 1995 and 2005, the proportion of Socialist women elected grew an average of 23.3 per cent, while between 1976 and 1995 it had grown approximately 13 per cent.

27. I.e. it is not written into the party statutes.

28. The Comparative Study of Electoral Systems, http://www.cses.org/ (accessed 10 September 2009).

29. The PCP consistently elected the highest percentage of women in all legislative elections, except in the 2005 and 2009 elections, when it was passed by the other leftist parties.

30. Two leaders, Marcelo Rebelo de Sousa (March 1996 to February 1999) and Durão Barroso (May 1999 to June 2004), particularly the latter, are associated with a period characterised by a greater level of concern with gender than either the previous period or the one directly following it.

31. In fact, some of the MPs interviewed were pro-quotas while others were against.

32. For a more nuanced analysis than space allows here, see Jimenez (2009).

33. The PS has been a full member of the Socialist International since 1973, one year after the organisation which eventually became the PS, the ASP, was admitted to the SI.

34. A similar law was instituted in France the same year.

35. This concept of a 'parity democracy' was launched by the Council of Europe in 1989, and both the PS and the BE have embraced it - at least in theory.

36. Namely, Proposta de Lei 40/VIII, DAR II série A No.59/VIII/1 2000.07.15 (1884-1891).

\section{References}

Bacchi, Carol (2006). 'Arguing for and against Quotas: Theoretical Issues', in Drude Dahlerup (ed.), Women, Quotas and Politics. New York: Routledge, 32-51.

Baum, Michael, and Ana Espírito-Santo (2004). 'Desigualdades de Género em Portugal: A Particípação Política das Mulheres', in André Freire, Marina Costa Lobo, and Pedro Magalhães (eds.), Portugal a Votos: As Eleições Legislativas De 2002. Lisbon: ICS, 261-99.

Baum, Michael, and Ana Espírito-Santo (2009). 'As Causas Para a Adopção da Lei da Paridade em Portugal', in André Freire and José Manuel Leite Viegas (eds.), Representação Política: o Caso Português em Perspectiva Comparada. Lisbon: Sextante, 375-414.

Baum, Michael, and André Freire (2003). 'The 1998 Portuguese Referendums. Explaining the Results and Speculating on the Future of Direct Democracy in Portugal', Portuguese Journal of Social Science, 2:1, 5-19.

Bettencourt, Ana Maria, and Maria Margarida Silva Pereira, eds. (1995). Mulheres Politicas as Suas Causas. Lisbon: Quetzal Editores.

Bird, Karen (2003). 'Who Are the Women? Where Are the Women? And What Difference Can They Make? Effects of Gender Parity in French Municipal Elections', French Politics, 1:1, 5-38.

Bonomi, Genny, Giorgio Brosio, and Maria Laura Di Tommaso (2006). 'How Italian Electors React to Gender Quotas? A Random Utility Model of Voting Behaviour', University of Torino, Department of Economics Working Papers.

Cabral, Manuel Villaverde (1997). 'Aspectos Da Condição Feminina Em Portugal', in Manuel Villaverde Cabral (ed.), Cidadania Política E Equidade Social Em Portugal. Oeiras: Celta, 79-97. 
Campos, Maria Amélia Clemente (2005). As Mulheres Deputadas e o Exercício do Poder Representativo em Portugal do Pós-25 de Abril Aos Anos 90. Porto: Edições Afrontamento. Caul, Miki (2001). 'Quotas: A Cross National Analysis', The Journal of Politics, 63:4, 1214-29. Comissão Nacional de Eleições (CNE) (2009). 'Mapa Dos Resultados Eleitorais', available at http://www.cne.pt/dl/resultados_ar2009_deputados_eleitos.pdf (accessed 15 November 2009).

Dahlerup, Drude, ed. (2006). Women, Quotas and Politics. New York: Routledge.

Dahlerup, Drude (2008). 'Gender Quotas: Controversial but Trendy. On Expanding the Research Agenda', International Feminist Journal of Politics, 10:3, 322-28.

Dahlerup, Drude, and Lenita Freidenvall (2005). 'Quotas as a "Fast Track" to Equal Political Representation for Women: Why Scandinavia Is No Longer the Model', International Feminist Journal of Politics, 7:1, 26-48.

Darcy, Robert, Susan Welch, and Janet Clark (1994). Women, Elections and Representation. Lincoln: University of Nebraska Press.

Da Silva, Maria Regina Tavares (1993). 'Até Quando Uma Meia Democracia? Construir a Paridade. Estratégias’, Organizações não Governamentais do Conselho Consultivo da CIDM.

De Sousa, Marcelo Rebelo, Luís Marques Guedes, and Luís Marques Mendes (1997). Uma Constituição Moderna Para Portugal: A Constituição da República Revista em 1997, Anotada por Luís Marques Guedes. Lisbon, Portugal: Edição do Grupo Parlamentar do PSD.

Espada, Isabel, Graça Vasconcelos, and Ana Coucello (2002). Género e Comportamento Eleitoral: O Eleitorado Português e a Actividade Politica das Mulheres. Lisbon, Portugal: Inst. de Estudos para o Desenvolvimento (IED).

Espírito-Santo, Ana (2006). Para Além das Cerejas: As Mulheres nos Principais Partidos Politicos Portugueses. Lisbon, Portugal: ISCTE.

Ferreira, Virgínia (1999). 'Os Paradoxos da Situação das Mulheres em Portugal', Revista Crítica de Ciências Sociais, No. 52-53: Fevereiro-Vinte anos de teoria social.

Freire, André (2001). 'Presidentes E Eleições Presidenciais No Portugal Democrático', in António Costa Pinto (ed.), Os Presidentes da República Portuguesa. Lisbon, Portugal: Temas e Debates.

Freire, André (2008). Sociedade Civil, Democracia Participativa e Poder Político. O Caso do Referendo do Aborto 2007. Lisbon, Portugal: Friedrich Ebert Stiftung.

Freire, André, and José Manuel Viegas (2009). Representação Politica Em Portugal. Inquéritos E Bases De Dados. Lisbon, Portugal: Sextante.

Freire, André, Manuel Meirinho Martins, and Diogo Moreira (2008). Para uma Melhoria da Qualidade da Representação. A Reforma do Sistema Eleitoral. Lisbon, Portugal, Sextante.

Global Database of Quotas for Women (2009). International IDEA and Stockholm University, available at http://www.quotaproject.org/ (accessed 12 June 2009).

Htun, Mala N., and Mark P. Jones (2002). 'Engendering the Right to Participate in DecisionMaking: Electoral Quotas and Women's Leadership in Latin America', in Nikki Craske and Maxine Molyneux (eds.), Gender and the Politics of Rights and Democracy in Latin America. New York: Palgrave, 32-56.

Inglehart, Ronald, and Pippa Norris (2003). Rising Tide: Gender Equality and Cultural Change around the World. New York: Cambridge University Press.

Jimenez, Antonia Maria Ruiz (2002). Mecanísmos del Cambio Ideológico e Introducción de Politicas de Género en Partidos Conservadores: El Caso de Ap-Pp en España en Perspectiva Comparada. Madrid: Instituto Juan March.

Jimenez, Antonia Maria Ruiz (2009). 'Women and Decision-Making Participation within Rightist Parties in Portugal and Spain', Análise Social, XLIV:191, 235-63.

Kittilson, Miki Caul (2006). Challenging Parties, Changing Parliaments: Women in Elected Office in Contemporary Western Europe. Columbus: Ohio State University Press.

Krook, Mona Lena (2006a). 'Gender Quotas, Norms, and Politics', Politics and Gender, 2:1, $110-18$

Krook, Mona Lena (2006b). 'Reforming Representation: The Diffusion of Candidate Gender Quotas Worldwide', Politics and Gender, 2:3, 303-27. 
Krook, Mona Lena (2007). 'Candidate Gender Quotas: A Framework for Analysis', European Journal of Political Research, 46:3, 367-94.

Krook, Mona Lena (2009). Quotas for Women in Politics: Gender and Candidate Selection Worldwide. New York: Oxford University Press.

Krook, Mona Lena, Susan Franceschet, and Jennifer M. Piscopo (2009a). 'The Impact of Gender Quotas: A Research Agenda', paper presented at the First European Conference on Politics and Gender, Queen's University Belfast, Northern Ireland.

Krook, Mona Lena, Joni Lovenduski, and Judith Squires (2009b). 'Gender Quotas and Models of Political Citizenship', British Journal of Political Science, 39:4, 781-803.

Lijphart, Arend (1999). Patterns of Democracy: Government Forms and Performance in ThirtySix Countries. New Haven, CT: Yale University Press.

Lovenduski, Joni (2005). Feminizing Politics. Cambridge, UK and Malden, MA: Polity Press.

Lovenduski, Joni, and Pippa Norris, eds. (1993). Gender and Party Politics. Thousand Oaks, CA: Sage Publications.

Matland, Richard E. (2006). 'Electoral Quotas: Frequency and Effectiveness', in Drude Dahlerup (ed.), Women, Quotas and Politics. New York: Routledge, 275-92.

Matland, Richard E., and Kathleen A. Montgomery (2003). Women's Access to Political Power in Post-Communist Europe. Oxford and New York: Oxford University Press.

Matland, Richard E., and Donley T. Studlar (1996). 'The Contagion of Women Candidates in Single-Member District and Proportional Representation Electoral Systems: Canada and Norway', The Journal of Politics, 58:3, 707-33.

Matland, Richard, and Michele Taylor (1997). 'Electoral System Effects on Women's Representation; Theoretical Arguments and Evidence from Costa Rica', Comparative Political Studies, 45, 186-210.

Meier, Petra (2004). 'The Mutual Contagion Effect of Legal and Party Quotas: A Belgian Perspective', Party Politics, 10:5, 583-600.

Meirinho Martins, Manuel, and Conceição Pequito Teixeira (2005). O Funcionamento Dos Partidos e a Participação Das Mulheres Na Vida Política e Partidária. Lisbon, Portugal: Comissão para a Igualdade e para os Direitos das Mulheres (CIDM).

Monteiro, Rosa (2011). 'Feminismo do Estado em Portugal: mecanismos, estratégias, políticas e metamorfoses, Vols. I e II', unpublished $\mathrm{PhD}$ thesis, FEUC, University of Coimbra.

Monteiro, Rosa (2011). 'A Política de Quotas em Portugal: o papel dos partidos políticos e do feminismo de Estado', Revista Crítica de Ciências Sociais, 92, 31-50.

Murray, Rainbow, Mona Lena Krook, and Katherine A.R. Opello (2009). 'Elite Bias, Not Voter Bias: Gender Quotas and Candidate Performance in France', paper presented at the First European Conference on Politics and Gender. Belfast, Northern Ireland.

Norris, Pippa, and Joni Lovenduski (1995). Political Recruitment: Gender, Race, and Class in the British Parliament. Cambridge and New York: Cambridge University Press.

Opello, Katherine A.R. (2006). Gender Quotas, Parity Reform, and Political Parties in France. Lanham, MD: Lexington Books.

Panday, Pranab (2008). 'Representation without Participation: Quotas for Women in Bangladesh', International Political Science Review, 29:4, 489-512.

Partido Comunista Português (PCP) (1979). 'Electoral Program, 1979 Legislative Elections', photocopy provided to authors.

Partido Socialista (PS) (1995). 'Electoral Program, 1995 Legislative Elections', photocopy provided to authors.

Paxton, Pamela, and Sheri Kunovich (2003). 'Women's Political Representation: The Importance of Ideology', Social Forces, 82:1, 87-114.

Público (2006). 'Cavaco Silva vetou Lei da Paridade', Público, 2 June, available at http:// publico.pt/1259248 (accessed 14 May 2009).

Rees, Teresa (1998). Mainstreaming Equality in the European Union: Education, Training and Labour Market Policies. New York: Routledge. 
Silveirinha Maria João, and Ana Teresa Peixinho (2008). 'The Law of Life and the Law of

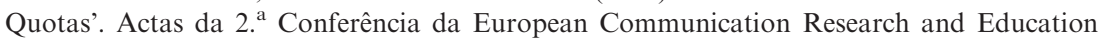
Association, Barcelona.

Soares Mário (1979). 'Relatório de Mário Soares, apresentado ao III Congresso Nacional do PS', photocopy.

Taagepera, Rein, and Matthew Soberg Shugart (1989). Seats and Votes: The Effects and Determinants of Electoral Systems. New Haven, CT: Yale University Press.

The Economist (2008). 'Quotas: Women Rising', 18 September, available at http://www. economist.com/world/international/displaystory.cfm?story_id=12260891 (accessed 24 March 2009).

United Nations Development Program (UNDP) (1995). Human Development Report: Gender and Human Development. New York: UNDP.

United States Agency for International Development (USAID) (2004). 'Civil Society Groups and Political Parties: Supporting Constructive Relationships, Doc. Id: Pn-Acu-631'. USAID Occasional Papers Series. Washington, DC: USAID Office of Democracy and Governance, Bureau for Democracy, Conflict, and Humanitarian Assistance.

Van Biezen, Ingrid (2003). Political Parties in New Democracies: Party Organization in Southern and East-Central Europe. New York: Palgrave Macmillan.

Vengroff, Richard, Lucy Creevey, and Henry Krisch (2000). 'Electoral System Effects on Gender Representation: The Case of Mixed Systems', Japanese Journal of Political Science, $1: 2,197-227$.

Viegas, José Manuel Leite, and Sérgio Faria (2001). As Mulheres Na Política. Oeiras: Celta.

Ware, Alan (1997). Political Parties and Party Systems. New York: Oxford University Press.

Zaller, John, and Stanley Feldman (1992). 'A Simple Theory of the Survey Response: Answering Questions versus Revealing Preferences', American Journal of Political Science, 36:3, 579-616. 